\title{
Yeni Türkiye Sinemasında Yetișkinliğe Geçiș: Sivas ve Hayat Var Filmlerinde Cinsiyet, Güç ve Oyun
}

\author{
Ebubekir Düzcan ${ }^{1}$
}

\begin{abstract}
Öz
Çocukluk, tarihsel olarak inşa edilmiş bir kavramdır. Tarih boyunca farklı anlamlara gelmiştir. Sinemadaki çocukluk imgesi de farklı zamanlarda farklı biçimlerde görünmektedir. Türkiye sinemasındaki çocukluk imgesi de zamanla büyük dönüşüm yaşamıştır. Çocukluk 1980 öncesi sinemada masum bir figür olarak görünürken, daha sonra kriz kaynaklı bir figüre dönüşmektedir. Özellikle 2000 sonrası Türkiye sinemasındaki çocukluğun farklı temalarından biri de cinsiyettir. Bu çalışmada Sivas ve Hayat Var filmleri örneği ile kız ve erkek çocukların yetişkinliğe geçiş sürecinin sinemada nasıl görünür olduğu analiz edilmeye çalışılacaktır. Çalışmanın temel kuramsal çerçevesi Connell'in "hegemonik erkeklik" kavramı ve Bourdieu'nün "erkeklik habitusu” üzerinden yürütülecektir. Sivas filmindeki köpek dövüşü oyunu, Bourdieu'nün homo-sosyal erkek topluluklar kavramı ve Huizinga'nın oyun kavramıyla birlikte analiz edilecek iken Hayat Var'daki kadınlık, hegemonik erkekliğin kadınlıkla ilişkisi ve ses kurgusu açısından değerlendirilecektir. Böylece erkekliğe ve kadınlığa geçişin farklı sinema anlayışları olan yönetmenler üzerinden değerlendirilmesi amaçlanmaktadır.
\end{abstract}

Anahtar Kelimeler: Çocukluk, Cinsiyet, Sinema, Sosyoloji, Oyun

\section{Transition to Adulthood in the New Turkish Cinema: Gender, Power and Game in Sivas and Hayat Var films.}

\begin{abstract}
Childhood is a historically constructed concept. It has been used in different meanings throughout the history. The image of childhood in cinema also appears in different forms at different times. The childhood image of Turkish cinema is also transforming in time. Childhood appeared as an innocent figure in the cinema before 1980, but later it became a crisis-based figure. One of the different themes of childhood in post-2000 Turkish cinema is gender. In this study, the examples of Sivas and Hayat Var movies will tried to be analysed focusing on how the transition period of boys and girls to adolescence appears in cinema. The main theoretical framework of the work will be conducted through Connell's concept of "hegemonic masculinity" and Bourdieu's "masculinity habit". While the dog fighting game in the Sivas film will be analysed together with Bourdieu's concept of homo-social male communities and Huizinga's game; femininity in Hayat Var will be evaluated in terms of the relationship with the femininity and sound fiction of the hegemonic masculinity. Thus, the transition to masculinity and womanhood will be evaluated through the perspectives of the directors who have different techniques in cinema.
\end{abstract}

Keywords: Childhood, Gender, Cinema, Sociology, Game 


\section{Giriș}

C ocukluk kategorisi, tarih boyunca farklı anlamlara gelmiş ve sanatsal üretim faaliyetlerinin odağında olmuştur. Çocukluğun sabit ve merkezi bir tanımının yapılamaması, onun temsilini "politik" bir mesele haline getirir. ${ }^{2}$ Nitekim, ço€ukluğun edebiyatta ya da sinemada nasıl kurgulandığı, dönemin toplumsal hayatı hakkında fikir yürütme olanağı sağlayabilmektedir. Fransız tarihçi Philippe Ariés'in 1960 yılında yazdığı ve 1962 yılında İngilizce'ye çevrilen Centuries of Childhood (Çocukluğun Yüzyılları) eseri, Ortaçağ'da bugünkü gibi bir çocukluk kategorisi olmadığını temellendirmektedir. Ariés'in bu çalışmasında Ortaçağ sanatını bir başvuru kaynağı olarak ele aldığı görülmektedir. Ariés (1962, 33), Ortaçağ'da çocukluğun yetişkinler gibi resmedildiğini söyleyerek, Ortaçağ'da modern anlamda çocukluk kategorisinin olmadığını iddia etmiştir. ${ }^{3}$ Temel okul sisteminin var olmasıyla çocukluk ve yetişkinlik arasındaki makasın açıldığı görülmektedir. Postman $(1995,53)$ ise yeni enformasyon çeşitliliğini öne çıkararak "çocukluğun kaybolduğunu"4 iddia eder. Öte yandan çocukluğun modern anlamda ortaya çıkışı, sinema yapan ilk aletlerin ortaya çıktığı dönemle de çakışır. Postman'a göre $(1995,83)$ çocukluğun doruğuna ulaştığı dönem 1850-1950 arası dönemdir. O halde sinema ve çocukluğun "modern" bir kategori olarak eş zamanlı çıktığı değerlendirilebilir. Böylelikle çocukluğun sinemadaki konumunun analizi çocukluğun ideal bir yurttaş olmasına dönük stratejilerin nasıl karşılık bulduğunu hatta bu tür inşacı analizlerin bize göstermediği çatışmacı deneyimlerin nasıl yaşandığını görmemizi sağlar. Örneğin "disipliner bir mekan"5 olarak "okul"un inşacı işlevselliğine yönelik çok şey söylenebilirken, sinemasal dünyadaki çocuk-okul karşılaşmaları, bunun tam tersine bu karşılaşmanın nasıl bir krize tekabül ettiğini, "söylem"in çocuğun ele avuca sığmazlığı karşısında nasıl etkisizleşip "kitabi" bulunduğunu deşifre etme potansiyeline sahiptir. ${ }^{6}$

Bu çalışmada Hayat Var (2008, Yön: Reha Erdem) ve Sivas (2015, Yön: Kaan Müjdeci) filmleri örneğinde çocukluğun sinemasal anlatı biçimindeki tarihsel dönüşümü ve bu dönüşümün sosyolojik karşılığı bağlamında analizi hedeflenmektedir. Ayrıca 2000 sonrasına geçmeden ve analiz edilecek filmlerin seçilme nedenini açıklamadan önce,

2 Özarslan'a göre “çocukluk dönemi”ni tanımlamak bebeklik dönemini tanımlamak kadar kolay değildir. Tarih boyunca, çocukluğa yüklenen farklı anlamlar, çocukluğu kurban etmekten yüceltmeye kadar çok çeșitli şekillerde çocuğu etkilemiştir.. Bu gibi nedenlerle çocukluk, tıpkı kadınlık gibi toplumsal ve politik bir kategoridir (Özarslan, 2016, 9-23).

3 Aries, eserinde Ortaçağ sanatında çocuk heykellerini analiz eder. Ancak sadece sanat çalışmalarına değil antik Yunan'daki temel eğitim düşüncesinin Ortaçağ'da kaybolduğunu, çocukların bebeklikten çıkar çıkmaz meslek hayatına atıldığını iddia eder. Ek olarak Aries'in Ortaçağ sanatı temelli analizinin eleştirilere de konu olduğunu hatırlamak gerekir. Ancak savunan ya da eleştiren çalışmalar, Aires merkezli bir biçimde çocukluk araştırmalarının zenginleşmesini sağlamıştır.

4 Postman özellikle çocuklukla yetişkinlik arasındaki enformasyon farkının, yeni gelişen kitle iletişim ağlarıyla kaybolduğunu ortaya koyar.

5 Disiplin mekanları kavramının mucidi Michel Foucault, okul, aile, hastane gibi kurumları bu kavram ışığında disiplinize edici özelliğiyle analiz eder. Disiplinin bu mekanlar aracılığıyla işlediğini ve böylece işlevsellik kazandığını iddia eder (Foucault, 2000, 211).

6 Okul ve temel eğitim düşüncesinin modernleşmenin en önemli enstrümanlarından biri olduğu yaygın bir görüştür. Ancak örneğin özellikle Yeni Türkiye Sineması'ndaki bazı örneklerde çocukların okulla karşılaşmaları farklıdır. Bu filmler, öğretmenin ezberci bir tonda kitaptan bir şeyler okuttuğu ve öğrencilerin ise başka dertlerle meşgul olduğunu gösterir. Sırasıyla Kasaba (1987, Yön: Nuri Bilge Ceylan), Hayat Var (2008, Yön: Reha Erdem), Sivas (2014, Yön: Kaan Müjdeci), Mavi Bisiklet (2015, Yön:Ümit Köreken) ve Rauf (2016, Yön:Soner Caner-Barış Kaya) filmleri buna örnektir. 
Türkiye sinemasında genel olarak egemen çocukluk kurgularına ve bu yöndeki filmleri tasnif ederken kullanılan anahtar kavramlara kısaca değinilecektir. Film analizinde Ryan-Kellner'in (2010, 40-41) "metaforik" ve "metonimik" kavramsallaştırması kullanılacaktır." Çocukluğu erdemleriyle değerlendiren filmler "metaforik" anlatı olarak değerlendirilecekken, çocukluğun toplumsal inşasına yönelik soru işaretlerini ve krizleri görünür kılan filmler ise "metonimik" kavramıyla değerlendirilecektir. Biraz daha açmak gerekirse, metaforik anlatı, belirli geleneklere ve otoriteye ve normlara sadık kalan, hatta egemen normların taşıyıcısı olarak geliştirilen anlatılardır. Yeşilçam filmlerindeki çocukluk anlatıları buna örnektir. Çocukluk, Yeşilçam'da genelde mutlu sonla biten "ailenin birliğini", "iyiliğin gücünü" veya "erdemli" olmayı ön plana çıkaran anlatılarda görülür. Bu duygular, toplumsal sorunların milli reçetesini tarif eden anlatılara dönüşür. Bu anlatıda haliyle, çocukluğun aile ya da okulla ilgili yaşadığı krizler, sınıfsal konumunun yarattığı kalıcı sorunlar veya yetişkinliğe geçiş eşiğinde yaşadığı cinsiyet problemleri görünmezdir. Bu deneyimler ise özellikle Yeni Türkiye Sineması'ndaki çocukluk temsilinde gözlediğimiz "metonimik" anlatıda devreye girer. Metonimik anlatı, çocuğu "çocuk" olduğu için haklı ya da erdemli ilan etmez. Onun eğitiminde, büyümesinde, yaşadığı çevrede veya cinsel kimliğinde oluşan deneyimleri sorunsallaştırır. Bu nedenle, metaforik anlatıyı çocukluğun "erdemler sineması" olarak kavramsallaştırırken metonimik anlatıyı çocukluğun "deneyimler sineması" olarak kavramsallaştıracağız.

\section{Erdemler Sinemasından Kopuș}

Çocukluk Türkiye sinemasında popüler biçimde ilk olarak Yeşilçam’la görünürlük kazanmıştır. Yeşilçam'ın anlatı formlarıyla ${ }^{8}$ uyumluluk arz edecek şekilde, çocukluk, ülke insanının doğasına ilişkin bir erdemliliği hatırlatan hatta yer yer bunu göze sokan "metaforik" hikayeler sunar. Gürbilek (2012: 39) edebiyatta da yaygın şekilde "çocuk kalmış millet” şemsiyesinde oluşan çocuklukla özdeşleşmeyi özellikle Sezercik, Ayşecik ve Yumurcak gibi 1960'lar ve 1970'ler Türkiye sinemasında popülerleşen imgeler üzerinden analiz ederek, çocuk kalmışııta yerli bir haysiyet ve Batı karşısındaki güçsüzlüğü formüle eden bir direniş oluştuğunu iddia eder. Böylelikle Gürbilek'in argümanından hareketle aile, vatan ve değişime dair dönemin önemli toplumsal meselelerinin bu filmler sayesinde alegorize edildiği söylenebilir. Abisel'e (1994: 83) göre de çocuk karakterli Yeşilçam filmlerinde, çocuklar kendilerini büyüten kişileri değil

7 Ryan-Kellner'e göre Metafor dikey ya da idealize edici eksen, metonimi ise yatay ya da maddeselleştirici eksendir. Metafor gelenek ve otorite ile ilişkilidir. Ayrıca genel bir retoriksel strateji olarak metafor bir imgenin önemini çıkarsamakta kullanılacak anlam kodlarını ifade eder. Diğer taraftan metonimi, düşünceyi yatay ve eşit olarak yönlendirir. Metonimide ise imge ya da işaret, kendisini bir parça olarak diğer bir parçaya bağlayan ya da parçasını oluşturduğu bir bütünle ilişkisini ifade eden bir şey anlamını taşır. "Hem... hem de..." önermeleri biçiminde çalışır. Metafor anlamın belirleyicisi ve gerçeğin çıkarımcısı olan otonom bir ego ima eder. İdeal anlamları maddesel imgelerin üzerine yerleştirmesi ve ilkini imtiyazlandırması nedeniyle dikey ve hiyerarşiktir. Örneğin metafor, bir kartalı özgürlük simgesi olarak şifrelerken, metonimi onu bir kuş yuvası, orman ya da soyu tükenmekte olan türler olarak görür. Metaforun gelenekselci yönelimine karşı, metonimi geleceğe yöneliktir, dinamiktir ve belirlenemezdir. Metonimi evrenselci ve kimlikçi değil, ampirik, farklılaşmış ve tikeldir; anlamı sabit kalıplar içinde belirleyen semantik eşitleme paradigmalarını yapıçözüme uğratır ve yıkar (Ryan-Kellner, 2010; 40-41).

8 Suner'e göre $(2006,30)$ 1960'ların ortalarından 1970'lerin ortalarına kadar en parlak dönemini yaşayan Yeşilçam'da üretilen filmlerin çoğu konu ve anlatım itibariyle birbirine benzeyen, istisnaları da olsa da genellikle aynı tip melodramlardan oluşmaktaydı. Çocukluk filmleri de aynı dönemin ürünü olarak genellikle tesadüflerle kayıp anne babasını bulan, iyi kalpli çocukların bedenlerinden beklenmeyecek büyük fedakârlıkları ve mücadeleyi gösterdikleri ve sonunda mutlu oldukları ya da kayıp anne babalarına ulaştıkları filmlerdir. Benzer konuları işleyen pek çok film çekilmiştir. 
de kan bağıyla bağlı oldukları yetişkinleri tercih ederler. O halde "metaforik" anlatının meşruiyetini tesis ettiği değerlerden biri de kan bağı bazlı aile anlayışıdır. Şüphesiz bu yönelim, ulusal değerlerin nasıl korunması gerektiğine ilişkin bir şemsiyedir.

Bu şemsiye kavramları kullanırken çocukluğun sadece Kemalettin Tuğcu uyarlamaları biçiminde filmlerde değil, aynı yıl çekilen Gelin (1973, Yön: Ö. Lütfi Akad), Canım Kardeşim (1973, Yön: Ertem Eğilmez) gibi filmlerde "metonimik" anlatı tarzıyla az da olsa görünür olduğu söylenebilir. ${ }^{9}$ Kısacası çocukluğun erdemleriyle değil başına gelen kalıcı olumsuzlukla ve hazin kurban edilişiyle ilgili anlatılar az da olsa 1970'ler sinemasının konuları arasındadır.

Şüphesiz metaforik çocukluk filmlerinin popülerliği "gecikmiş modernlik" kavramının yara sarma girişimlerinden biri olarak da okunabilir. ${ }^{10}$ Buna ilave olarak, bu filmlerin özellikle 1990'ların ortalarına kadar sıklıkla TV'lerde uzun süre anlamlı bulunduğu da değerlendirilebilir. Ancak buna karşın 2000'ler sonrasında "erdemler sinemasının" yahut Kellner-Ryan'ın (2010: 40-41) kavramsallaştırmasıyla "metaforik" filmlerin inandırıcılığını -özellikle Yeni Türkiye Sineması'nda- büyük ölçüde kaybettiği söylenebilir.

Ancak Suner'in tespiti doğrultusunda 'çocuk millet' tasavvurunun 'toplumsal çocukluk dönemi”ne atıf yapılarak, özellikle popüler Türkiye sinemasında da etkisini sürdürdüğüne vurgu yapılabilir: "Çocukluk öyküleri, çocuk kahramanlar aracılığıyla değil, aslında birer yetişkin olan kahramanların 'çocuksulaştırılması' yoluyla kurulmaktadır" (Suner, 2006: 73). Suner bu tespitiyle, örneğin Eşkıya (1996, Yön: Yavuz Turgul), Komser Şekspir (2001, Yön: Sinan Çetin), Dar Alanda Kısa Paslaşmalar (2000, Yön: Serdar Akar) ve Vizontele (2001, Yön: Yılmaz Erdoğan) gibi Yeni Türkiye Sineması'nın "popüler" filmlerinde çocukluğun olmasa bile "çocuksu ruh"un devam ettiğini iddia etmektedir. Suner'e (2006: 73-83) göre bu filmler, şimdiki zamana odaklı olsalar da bugünü kötülükle, geçmiş mekânını da mutlulukla, masumiyetle ve çocuksulukla özdeşleştirirler. Adı geçen filmler bu sayede, "çocukluğun masumiyetine duyulan özlem"i formüle ederler.

Popüler Türkiye sinemasını istisna olarak görürsek, Ömer Kavur'un Yusuf ile Kenan (1979) filmiyle birlikte çocukluğun sinemada "metafor"dan "metonimi”"ye geçiş yaptığı söylenebilir. Filmde kan davası sebebiyle İstanbul'a gelen ve sokakta yaşamak zorunda kalan iki kardeşin farklılaşan mücadelesi anlatılır. Büyük kardeş Yusuf (14), şehrin tehlikeli iliş̧iler ağı içerisinde "kısa yoldan köşeyi dönme" odaklı bir suç

9 Adı geçen filmler, Yeşilçam döneminde çekilmiş ancak metaforik bir anlatıya sahip olmayan istisna filmlerdir. Bu filmler, çocuk kahramanlı diğer popüler Yeşilçam filmlerinin aksine, çocuğun içine yaşadığı ailenin sosyoekonomik yetersizliklerinin yarattığı tahribata odaklıdır. Gelin, ailenin kazanma hırsının çocuğu kurban etmeye varacak derecede kapitalist ruhla iç içe geçtiğini anlatan bir göç filmiyken, Canım Kardeşim, ekonomik yetersizliklerin ve sağlık sorunlarının çocuğun hayallerini kesintiye uğrattığını ve yaşamdan alıkoyduğunu anlatan ana akım sinema örneği bir gecekondu filmdir.

10 Jusdanis, gecikmiş modernleşme kavramıyla, modernleşmeye yetişmeye çalışan toplumların, telaşlı ve tedirgin bir çaba içerisine girdiğini iddia eder. (Jusdanis, 2015). Ayşecik filmlerindeki çocukluk temsiline odaklanan çalışmasıyla Kumru Berfin Emre, (2007) Ayşecik filmlerinde gecikmiş modernliğin izlerini ortaya koyar: "Türkiye modernleşmesinin gecikmişliği, kimi zaman çocuksu yetişkinlerle kimi zaman da toplumun acizlik, yetimlik, yoksunluk duygularıyla birlikte masumiyetin ve saflığın da simgesi olan çocuk kahramanlarla özdeşlemesine neden olmuştur. Kimsesiz, sahipsiz fakat güçlü Ayşecik de bu kahramanlardan biridir." (Emre, 101). 
şebekesinin üyesi olmayı seçerken, küçük kardeş Kenan (12) ise "bileğinin hakkıyla" bir işçi çocuğunu örnek alarak emeğinin, "onurlu" ve "erdemli" yaşamın peşinden gitmeyi tercih eder. Bu yol ayrımı, erdemlerle deneyimler arasında bir yol ayrımı olarak değerlendirilebilir. Film, Kenan'ın tercihinin toplumsallığıyla "metaforik" hikayelere atıf yaparken, Yusuf'un tercihinin toplumsallığıyla "metonimik" hikayeleri andırır. ${ }^{11}$

Bir anlamda Kemal Sunal filmlerinin dahi biçim değiştirdiği bu yeni dönemde ${ }^{12}$ Öğretmen (1988, Yön: Kartal Tibet) ve Düttürü Dünya (1988, Yön:Zeki Ökten) gibi örneklerde görüleceği gibi, çocukluğun huzur ve saadeti çağrıştıran görüntüsünden uzaklaşmaya başladığı görülmektedir. Bu dönemde sinema, sınıfsal konumun yarattığı sıkışmışıı içerisinde yer alan karakterleri içeren yeni konularla ilgilenmeye başlar. Yahut Duvar (1984, Yön: Yılmaz Güney), Uçurtmayı Vurmasınlar (1989, Yön: Tunç Başaran), Babam Askerde (1995, Yön: Handan İpekçi) ve Büyük Adam Küçük Aşk (2001, Yön: Handan İpekçi) gibi filmler ile çocukluk, politik bir alegori nesnesi olarak "başka" sorunları göstermede bir imge olmaya başlamıştır. Çocuk bedeni bu filmlerde, korunaklı bir liman olarak değil, politik sorunların taşıyıcısı, tanığı ve mağduru olarak ele alınmaktadır. Çocukluk, böylece "metaforik" anlatıda olduğu gibi sınıfsal konumundan ve politik öznelerin çatışmasındaki etkileşimden münezzeh değildir. Bu doğrultuda, Yeni Türkiye Sineması'nda yaygınlaşacak "metonimik" filmlerin ortaya çıkmaya başladığı değerlendirilebilir.

Yeni Türkiye Sineması'nda çocukluk bu nedenle, toplumsal sorunların, yabancılaşmanın yahut modern krizlerin gösterilmesi noktasında alegorinin, taşranın, hatırlamanın veya büyümenin anlatımı için tercih edilir olmuştur. Kasaba (1997, Yön: Nuri Bilge Ceylan), Beş Vakit (2006, Yön: Reha Erdem), Bal (2010, Yön: Semih Kaplanoğlu), Kuzu (2014, Yön: Kutluğ Ataman) ve Rauf (2016, Yön: Soner Caner-Barış Kaya) filmleri kamerayı taşra mekanına çevirirken, çocukluğun taşra mekanındaki sorunlarına ve çeşitli krizlerine odaklanırlar. Kızıldaş (2016: 72), Yeşilçam sinemasındaki mutlu, huzurlu ve farklılıkların bir arada yaşandığı hoşgörü ortamı olarak "bizim mahalle" imgesinin Yeni Türkiye Sineması'nda yerini "dışarda kalan" imgelerden biri olarak taşraya bıraktığını erkek filmleri üzerinden tespit eder. Yeni Türkiye Sineması'ndaki çocukluğun dönüşümü de, bu türden genel bir arayışla uyumludur.

\section{Iki Dil Bir Bavul (2009, Yön: Orhan Eskiköy, Özgür Doğan), benzer bir arayışın}

111979 yılında çekilip 1980'de vizyona giren film, Ömer Kavur'un politik yanı ağır basan filmlerinden biri olarak değerlendirildiği görülmektedir. Dönemin sosyal siyasal çatışma ortamında, Kavur, özellikle Yusuf ve Kenan'a sermaye sahiplerinin kibirli yaklaşımını aktarırken eleştirel bir okumaya olanak tanır. Buna mukabil filmin, çocuk yaşta işçiliği bir reçete olarak ortaya koyması nedeniyle eleştirildiği de anlaşılmaktadır. Bu ve benzeri eleştirel fikirlerin okuması için Bkz. Gülay Yüksel, Eleştirel Bir Ömer Kavur Filmografyası Denemesi, Yakın Doğu Üniversitesi Sosyal Bilimler Enstitüsü, Yayımlanmamış Yüksek Lisans Tezi, 2013, Lefkoşa.

12 1980'li yıllarla birlikte Yeşilçam anlatı formunun terkedildiği görülmektedir. Bu dönüşüm, Kemal Sunal filmlerine de yansır. Şaban serisi filmleri dışında "dram" yönü ağır basan yeni dönemin Kemal Sunal filmleri de bu doğrultuda "metonimik" çocukluk anlatısı dediğimiz temsilleri yaratma potansiyeline sahiptir. Kemal Sunal, (1998)bizzat kendisinin yazdığı yüksek lisans tezinde "dram yönü güldürünün önüne geçen filmler" başığı koyarak tarih aralığı olarak da 1986-1981 arasını işaret eder. Bkz. Sunal, Kemal, TV ve Sinemada Kemal Sunal Güldürüsü, Marmara Üniversitesi Sosyal Bilimler Enstitüsü, Yüksek Lisans Tezi, 1998. Aynı isimle basılı hali için Bkz. Sunal, Kemal, Sel Yayıncılık, 2005. Öğretmen (1988, Yön: Kartal Tibet) ve Düttürü Dünya (1988, Yön:Zeki Ökten) filmleri bu anlamda, çocukluğu sadece yetişkin erdemleriyle temsil etmez. Öğretmen de çocuklar, öğretmenlerinin geçim sıkıntısı nedenli psikolojik ve maddi sorunlarını yetişkinlerin ilgisizliği çerçevesinde çocuksu şekilde onarmaya çalışıllar. Bunu yaparken, farklı deneyimlere farklı sınıflara ve farklı psikolojilere ait oluşlarıyla tek tip değillerdir ve ekonomik sıkıntılardan kendileri de etkilenmektedir. Düttürü Dünya ise, engelli çocuk karakteriyle, çocukluğun metaforikleşmesini engelleyen bir biçim sunar. 
örneği olarak eğitimde dil sorununu çocuğun karşılaştığı travmatik bir vakıa olarak belgelerken, Mavi Bisiklet (2015, Yön: Ümit Köreken) ise, otorite, demokrasi ve halk arasındaki ilişkiyi betimlemek için sınıf başkanlığını demokratik yolla seçmek isteyen çocukların mücadelesi üzerinden bir demokrasi alegorisi ortaya koyar.

Sonuç olarak 2000'ler sonrası Türkiye sinemasındaki çocukluk imgesinin, masumiyetle yahut erdemleriyle değil, yetişkinliğe sarkan sorunlarıyla gündeme geldiği görülmektedir. Bu filmlerde göze çarpan ve üzerinde duracağımı önemli temalardan biri de yetişkinliğe geçiş sürecidir. Şüphesiz bu filmler, erdemler sinemasından kopuşa yönelik önemli izler taşısa da çocukluğa yine de bir takım erdemlerin yapışık olması "metonimik" anlatı kavramının daha etkin bir tanım olduğunu göstermektedir. Bu yüzden yetişkinliğe geçişin sinemada neden bir "kriz" olarak sorunsallaştırıldığına bakmak gerekmektedir.

\section{Büyüme Sancısı ve Çocukluk}

Büyüme hikayeleri, sinema filmlerinde sıklıkla görülen bir anlatıdır. Masum çocukluk anlatılarından en önemli farklılığı çocuğun cinsiyetinin artık görünür olması ve bir krize işaret etmesidir. Zira, masum çocukluğa dayalı erdemler sinemasında çocuğun cinsiyetsizleştirildiği görülmektedir. Daha doğru bir deyişle, ailenin birliğinin yahut öz anne ve babanın yüceltilmesine dayalı "metaforik" anlatı, çocuğun cinsiyetinin gerektirdiği "metonimik" ayrıntıları yutma kudretine sahiptir. Ancak bu genel eğilime rağmen, erdemler sinemasının kız çocuk kahramanlı filmleriyle erkek çocuk kahramanlı filmlerinin, cinsiyet ve anne-baba gibi rol modelleri arasında kurulan belirli ayrışma noktaları vardır. Örneğin Sezercik ve Ayşecik'in cinsiyet farkından kaynaklanan farklı toplumsal rolleri buna örnektir. Ayşecik Şeytan Çekici (1960, Yön: Atıf Yılmaz) filminin başında Ayşecik karakterinin bebekliği gösterilir. Sonrasında Ayşecik'in bebeklikten çocukluğa geçtiğini gösteren sahnelerde ise Ayşecik, çamaşır asmakta, yemek pişirmekte ve ortalığı toplamaktadır. "Ayşecik'in bebeklik evresinden çocukluğa geçişi, çocuk kültürüne ilişkin oyun oynamak gibi bir eylemle değil, toplumsal kadınlık rolü ile anlatılır" (Emre, 2007: 85). Tersi bir örnek olarak Sezercik Küçük Mücahit (1974, Yön: Ertem Göreç) filminde ise erkek çocuğun yaşından beklenmeyecek kahramanlık ve askeri başarı gösterdiği vurgulanır. Benzer örnekler, erdemler sinemasındaki çocukluk hikayelerinde, egemen toplumsal cinsiyet normlarının da metaforik anlatının bir parçası olabildiğini göstermektedir.

Ancak çocukluğun büyüme süreci söz konusu olduğunda "erdemler"in ve egemen toplumsal normların değil çeşitli krizlerin görünür olduğu söylenebilir. Bu sadece çocuğun içkin bir şekilde doğasında olduğu varsayılan erdemlerin kaybolması anlamına gelmez, aynı zamanda çocukluğu saran yetişkin dünyasının da bu erdemleri pek dikkate almadığı anlamına gelir. Aileyi birleştiren, "vatanı kurtaran" ve büyüklere ders veren çocuksu erdemlerin yerini tedirginlik kaynağı bir çocukluk kurgusu almaya başlamaktadır.

Büyüme söz konusu olduğunda erdemlerin görünmezleşmesine ek olarak Yeni Türkiye Sineması'nda kötülüğün, suçun ve ihlalin bir çıkış olarak görülmesi ${ }^{13}$ çocukluğun da

13 Arslan'a (2004:165) göre 1970'lerin sinemasında popüler olan erkekliğin suça, şiddete ve intikama bulaşma hikayesinin altında 1960 'ı yılların çocuk kahramanlı filmlerinin gerçeklik anlayışının ve erdemlere dayalı fantezi 
"kötücüllüğe" doğru savrulmasını işaret eden yeni bir temsiliyettir. Böylelikle çocukluk, bir an önce büyümek isteyen bir zaman ve mekanda işlenmiştir. Yeni Türkiye Sineması'ndaki çocukluk kodları bu yüzden, çocukluğu yetişkinlikle ilişkisi etrafında çözümleyen deneyimler sineması olarak karşımıza çıkar. Deneyimler sinemasında, taşrada ya da şehirde olsun farklı mekanlardaki çocuklar, masumiyetlerini "kaybedip" yetişkinliğe adım atarlar. Bu geçiş aynı zamanda, yetişkinlerin "kendi masumiyetlerine duydukları inancın" kaybı anlamına da gelir. Böylece çocukluk temsili, masumiyeti yok edilip onarılarak daha inandırıcı hale gelmektedir.

Kısacası 2000'li yıllarda artık "hayali" ve "masum" çocukluk paradigmasının en azından sinemada işlevsizleştiği ve çocukluğun yetişkinliğin iktidar düzeneklerinin bir parçası olarak yeniden "minyatür yetişkin" olarak kodlandığı görülür. Postman'ın "çocukluğun kaybolduğu" iddiasıyla (Postman, 1995:145) paralel biçimde çocukluğa yönelik kuşatma, yetişkinlerle at başı gittiğinde çocukluk kategorisinin özerk bir alanı kalmamakta ve yetişkinlerle aynı anda enformasyona ulaşabilen çocukla yetişkinlik arasındaki fark da azalmaktadır. Zira, artık çocuğu iktidardan uzakta değerlendirmek pek mümkün değildir. Bu yakınlaşma sadece enformasyona ulaşma açısından geçerli değildir. Onunla birlikte yetişkinleri kuşatan iktidar mekanizmalarının da eş zamanlı olarak çocuklara da ulaştığı kabullenilmiştir. Bu demektir ki, iktidar Foucaultcu anlamda aileyi de kuşatacak biçimde, çocukluğun nelerle karşılaştığını hesap eden, baskıcı değil, sevk eden bir işlevselliktedir ve çocukluğu da etki alanına çoktan almaktadır. Böylece yetişkin krizlerinin çocuklukla temasının da önü açılmakta ve çocukluk, cinsiyetle birlikte krizi de ima etmektedir.

Postman'a (1995: 110) göre modernliğin ürünü filtrelerin, çocukların her şeye ulaşabileceği yeni elektro- dünyada işlevsizleşmesi "çocukluk" kategorisini de ortadan kaldırmıştır. Çocuklar artık "hayret etmez" olmuşlar ve "ayıp"ı bir sınır ihlali olarak kodlamak beyhude bir çaba olarak geride kalmıştır. Yetişkinlik, modern krizlerle çocuğa uygulayabileceği otoriteyi de kaybetmiştir. Hatta kimi zaman bu otoriteyi uygulayan bizzat çocuğun kendisi dahi olabilmektedir. Sivas'ta (2015, Yön: Kaan Müjdeci) sahip olduğu dövüş köpeğiyle yaşından bağımsız "erkekler dünyası"nda söz sahibi olan Aslan'ın buyurgan konumu buna örnektir. Çünkü otoriteyi biyolojik yaşla ilişkilendirmek bir hakikati işaret edemez hale gelmiştir. Normların çoğu çocuk için merak unsuru olmaktan çıkmıştır. Bu havuzda çocukken yüzmeye başladığı için, iktidar kipleri sürekli kayganlaştığı için ve yetişkin muktedirsizleştiği için çocuksu "oyunbozanlık" normların daha kolay altüst edilebilmesine yol açmıştır. Yetişkinden yansıyan doğal aktarımlarla tabi haline gelen çocukluk gitmiş onun yerine zaten aynı düzenek yağmuru altında olan çocukluk gelmiş ve yetişkinlik, bu "normlar" için çocuğa sürekli izahat verir duruma gelmiştir.

Bu bakımdan çalışmada yukarıda sözü edilen dönüşümün yarattığı büyüme kurgusu, toplumsal cinsiyet ve çocukluk açısından değerlendirilecektir. Böylelikle hem çocukluk çalışmalarıyla hem de toplumsal cinsiyet çalışmalarıyla diyalog içerisinde olmak gerekmektedir. Bu anlamda Bourdieu'nün "eril tahakküm" analizi çerçevesinde "erkeklik habitusu"14 (2015:21) kavramsallaştırması ve Connell'in (1998: 247) "hegemonik

anlayışııın yıkılması yatmaktadır. Bu reddiye Yeni Türk Sineması'nın çocukluk kurgularının da paylaştığı formlardan biridir.

14 Bourdieu'ye göre habitus, bireyleri kültürel olarak belli şekilde davranmaya yönelten bir eğilimler ve 
erkeklik"15 kavramsallaştırmasından istifade edilecektir. Sivas filmi, erkekliğin üretimini, muhtar karakterinin adeta erkekliği onaylayıcı ve belirleyici biçimde merkezde olduğundan hareketle, "hegemonya" kaynaklı olarak temsil etmektedir. Hegemonik erkekliğin sadece kadınları değil, öncelikle erkekleri etkilediğini iddia eden Connell'in tespitleri uyarınca, erkekliğin erkeklik üzerindeki öncü etkileri önem kazanmaktadır. Brannon ise, erkekliği dört temel faktörle tanımlar: tüm kadınsı davranışlardan kaçınma, statü, ekmeğini kazanma yetkinliği, güç ve saldırganlık (Brannon'dan akt. Atay, 2004:11-12). Öte yandan Bourdieu, erkek homo-sosyal ${ }^{16}$ topluluklar içerisinde yaşanan rekabet oyunlarının erkek habitusunu şekillendirdiğini söyler. Bu oyunlar -düello gibi- erkek onuru kavramını üretir ve erkekliği ispata çağırır (Bourdieu'dan akt. Onur ve Koyuncu, 2004:32-33). Bu nedenle Sivas filmindeki köpek dövüşü oyunu mekanı, bu tür rekabet oyunlarının yaşandığı homo-sosyal bir erkek mekanı olarak değerlendirilecektir.

$\mathrm{Bu}$ nedenle Sivas filminde cinsiyetle birlikte güç ve oyun kavramlarına da odaklanılacaktır. Oyun, bir ucu hala çocuklukta kalan bir toplumsallaşma biçimini işaret ederken, güçlü olmak ya da olamamak hali de cinsiyetin kız ve erkek çocuğun toplumsallaşma sürecindeki elbiselerinden birisidir. ${ }^{17}$ Örneğin Sivas'ta (2015) erkekliğe geçişin oyunsu güç gösterisini, icra edilen ve bir "aslan parçası"na dönüşmesi beklenen toplumsallığında görebilirken Hayat Var'da (2008) kadınlığa geçişin nasıl bir toplumsal sessizliğe ve çaresizliğe gömülü olduğunu görürüz. Connell'e (1998: 245) göre "hegemonik erkeklik" kadınlığı etkilese de "hegemonik kadınlık" söz konusu değildir. Çünkü erkeklik en çok erkeği ezer. Berktay’a (2016: 30) göre bunun nedeni kadınların direnme biçimleri yaratmada daha elverişli bir konuma sahip olmalarıdır. Bu, kadınların ezilen bir grup olarak merkezden daha uzak olmalarından kaynaklanır. O halde kadınlık, öncelikle "direniş" pratiği üzerinden sorunsallaştırılabilir. Hayat Var'da, Hayat'ın hayal kırıklıklarını ve tepkiselliğini yansıtan direnişler ve sonraki bölümde detayına girilecek non-diegetic seslere yansıyan durumlar bu nedenle çalışmamızın analiz edeceği pratiklerdir. Tannen'e göre (Akt. Atay, 2001: 12) toplumsal kadın kimliği erkek kimliğinin aksine daha çok uzlaşmacıdır ve çatışmadan uzaktır. Çünkü çatışma, bağlantı kurmaya yönelik bir tehdittir. Hayat'ın direniş pratiği kadar, uzlaşmaya yaklaştığı durumlar da bu nedenle analiz edilecektir.

Detaylandırmak gerekirse çocukluk merkezli kadınlık-erkeklik ayrımını daha net ortaya koymak için Sivas (2015, Yön: Kaan Müjdeci) ve Hayat Var (2008, Yön: Reha Erdem) filmleri örnek olarak seçilmiştir. Söz konusu filmlerin seçilme nedeni öncelikle

yatkınlıklar sistemidir. İçselleşmiş ve yatkınlığa dönüşmüş zorunluluklardır. (Swartz, 2011, 136). Erkeklik de bu nedenle bir "erkeklik habitusu" biçiminde işler. Bourdieu'ye göre cinsler arası bölünme zora değil gönüllü itaate ve rızaya dayalı biçimde bireylerin bedenlerine gömülmüş halde habituslarında mevcut haldedir $(2015,21-53)$ Sancar'a $(2013,189)$ göre de, habitusu toplumsal cinsiyet üzerinden tartışmak, feminist düşünceye de yeni atılımlar sağlar.

15 Connell'e göre "hegemonik erkeklik, erkekler arası ilişkilerin ana temelini oluşturur. Daima kadınlarla ilgili olduğu kadar, ikincil konuma itilmiş erkeklik biçimleriyle ilgili olarak da inşa edilmektedir. Farklı erkeklik biçimleri arasındaki etkileşim, ataerkil bir toplumsal düzenin işleyiş biçiminin ayrılmaz parçasıdır" (1998:247). Connell Gramsci'den ödünç aldığı bu "hegemonya" kavramını, silah zoruyla ve salt fiziki üstünlüğe dayalı bir üstünlük olarak görmez. Bu nedenle kavramı, Bourdiue'nün "habitus"uyla birlikte değerlendirmek mümkündür.

16 Sadece erkeklerin yer aldığı topluluklar. Yanı sıra, Yeni Türkiye Sineması'nın taşra erkeklerini homososyal topluluk olma yönünden inceleyen bir çalışma için Bkz.Kızıldaş, Burçin Kalkın, Taşra Kalan Erkeklikler, SineCine, 2016, Güz 7(2). Sf.71-94.

17 Bourdieu'ye göre (2015:66) şeref, erillik merkezli toplumsal oyunlar, erkeği tam erkek yapar ve kadınlar bu alandan dışlanır Winnicot'ta göre de kültürel deneyim, oyunla başlar (2014: 126). 
her iki filmin de "çocukluktan yetişkinliğe geçiş" filmi olarak değerlendirilmesidir. Hayat Var'da ilk adet kanaması geçiren Hayat, annesi tarafından "kadın oldun!" diye tokatlanmaktadır. Sivas'ta ise Aslan, annesi tarafından yıkanırken "erkek mi oldun sen?" diyerek temizlenmektedir. Bu önemli sahneler dışında, her iki filmin karakterleri de Yeşilçam'ın "erdemli" çocuklarından farklı olarak "asi" çocuklardır. Her ikisi de ailesiyle problemler yaşayan başına buyruk özellikleri olan karakterlerdir. Ancak her iki filmde de "hegemonik erkekliği" uygulayabilen güçlü babalar değil nisbeten aciz babalar söz konusudur. ${ }^{18}$ Yanı sıra her iki filmin yönetmeni de "Yeni Türkiye Sineması" içerisinde değerlendirilmiştir. Reha Erdem, 1990'lı yıllarda ilk filmlerini çekmiş bir yönetmenken, Kaan Müjdeci'nin uluslararası festivallerden de ilgi gören filmi Sivas, onun ilk filmidir. Öte yandan seçilen filmlerin farklılıkları da onları birlikte değerlendirmeyi verimli kılmaktadır. Reha Erdem, aşağıda değinilecek başka filmlerle de "büyüme" temasını işlemiş deneyimli bir yönetmenken, Kaan Müjdeci henüz ilk filmini çekmiştir. Gerçekçi bir anlatım dilini benimseyen Müjdeci'ye karşın, Erdem, "gerçeküstü" bir anlatım diline sahiptir. Bu nedenle, her iki filmi, sadece erkekliğe ve kadınlığa geçiş yapan karakterlerinin hikayeleri üzerinden değil kamera kullanımı -ve özellikle Hayat Var içinses kullanımıyla da analiz etme gereği oluşmaktadır.

\section{3. İsimsizler Mekanında Hayat' in Kendisi ve Mirıltıs ${ }^{19}$}

Hayat Var'da (2008, Yön: Reha Erdem) Hayat ve ailesi Reha Erdem'in sesler ve görüntüler eşliğinde yarattığı gerçeküstü ${ }^{20}$ ve sisli bir atmosfere sahip boğaz kenarında bir kulübede dede, baba ve torun birlikte yaşarlar. Hayat, "çocuk masumiyetine dair kafamızda yaşayan kalıplara sığmayan bir karakterdir" (Yücel, 2012: 87). İstanbul boğazının taşrasında yaşayan bu ailede astım hastası yatalak dede, sürekli eski İstanbullu olmakla övünen huysuz ve küfürbaz bir yaşlıdır. Baba ise salıyla boğazdaki büyük gemilere kadın ve içki satar. Seçmek zorunda kaldığı meslek, yaşadığı koşullar onun "hegemonik erkek" olarak değil çaresiz bir erkek olarak tasvir edildiğini ortaya koyar. Ancak Hayat'ın üvey babası olan ve Hayat'a verdiği uyarılarla karşımıza çıkan polis baba ise, "hegemonik erkekliği" işaret edecek biçimde "mesleğinden gelen gücüyle düzen koruyucu, iktidarın simgesi, güç ve otorite sembolü olan silahın sahibidir" (Gürses-Becerikli, 2016: 8).

Dedesi gibi astım hastası olan Hayat'ın arada yanında kaldığı annesi ise başka bir adamla evlenmiş ve bir erkek bebek sahibi olmuştur. Vaktini ve ilgisini bu bebeğe ayırmaktadır. Hayat ise bu denklemde, okulda "kötü kokuyorsun" diye dışlanan, annesi tarafından "kadın oldun!" diye tokatlanan ve bakkal tarafından tecavüz edilen bir ortaokul öğrencisidir.

18 Sivas filminde baba, erkekliğin performe edildiği ve filmin merkezi hattı olan homo-sosyal topluluklarda yani filmdeki köpek dövüşü alanında yoktur, Aslan'a abisi ile kavga ederken müdahale etse de sözünü ona tamamen geçirebiliyor değildir. Hayat Var filmindeki baba ve hatta dede ise Hayat'ın yardımına muhtaçtır. Hayat'a karşı müdahil uyarıcı yönlendirici davranışlar içerisinde değildir. Hapse girişiyle Hayat'ı okula götürmekten de alı koyulur.

19 “Mırıltı" alt başşı̆ının esin kaynağı Nilüfer Erdem'in (2012) "Hayat'ın Mırıltısı" adlı makalesidir. Hayat'ın davranışları, filmde sadece eylem merkezli değil aynı zamanda ses merkezlidir.

20 Reha Erdem filmlerinin genel özelliklerini bu noktada hatırlamak yararlı olacaktır. Gerçeküstü anlatım tarzı, Reha Erdem filmlerini gerçekçi film anlayışından ayırır: "Gerçek denilen şeyle kıyaslama yapmak için üretilmemiş, tersine böyle bir bakışın önünü tıkayan bir sinema vardır karşımızda. (..) Gerçek yaşama fena halde benzeseler de, natüralist addedilen filmlere benzemezler. "(Yücel, 2009: 8-9). 
Astım hastası Hayat, içinde yaşadığı bu durumda yetişkinliğe adeta maruz kalır. Sanki doğrudan kendisini kadınlığın içinde bulmuştur ve yaşamadığı çocukluğu arzulamaktadır. ${ }^{21}$ Sürekli mırıldanışı, parmağını emmesi, kardeşinin salıncağıyla ve emziğiyle oynaması yaşayamadığı çocukluğa kaçıp "nefes almak" gibidir onun için. Yanı sıra filmde Hayat dışında hiçbir karakterin ismini öğrenemeyiz. İsimlerinden bağımsız diğer kimliklerin yanında, "kayıp" sanılan bir gerçeklik "hayat var!" denilerek özellikle öne çıkarılır.

Hayat kelimesi içinde barındırdığı tüm umutlara rağmen argoda "hayat kadını" olarak kullanılır. Babanın fahişe arkadaşı da Hayat'ın güzelliğine bakarak "işimizi elimizden alacaksın" derken ona çizdiği kader güzergahı görünüyordur. Hayat, böylece çocukluktan hızlıca çıkmaktan başka çaresi olmayan bir güçsüzlük olarak çizilir.

Bakkal tarafından uğradığı tecavüzden sonra, bakkaldan tomarla çikolata alması çaresiz bir farkındalığa işaret eder. Ancak bu farkındalık, halen çocuksu bir sessizliğin içine gömülür.. Tecavüzden sonra komşu yaşlı kadın Hayat'ı "benim de başıma gelmişti” diyerek teskin eder. Böylece kadınlık, erkeklik gibi mücadele ederek ve Tannen'in yukarıda andığımız tespitiyle uyumlu biçimde kendini göstererek değil, sessizlikle ve çaresiz bir uzlaşmacılıkla kurulur. Bu yaşananların bir gizliliğe gömülmesi intiyacı böylece onaylanmış olur. Buna rağmen aynı komşu kadın, nefretle gidip o bakkalın camlarını ve aynasını kırar. Cinsellik, Hayat'ın dünyasında hala tüm şiddetiyle "doğal" bir maruz kalma halidir. Ancak tesadüfen de olsa o aynayı tamir eden ve kendi eliyle aynayı taşıyan kişinin Hayat'ın babası olması ise bu anlatı için oldukça manidardır. Çünkü bu simgeyle, kız çocukluğundaki tahribatın erkeklik tarafından "onarılan" ve bu sayede üstü örtülen bir sessizlik olduğunu gösterir.

Orhan Gencebay şarkılarıyla Hayat'la iletişim kurmak isteyen ve yüzünü Fenerbahçe'nin renklerine boyayan tamirci çırağı erkek çocuğun sürekli gideceği bir "maç" vardır. Ancak, babası gelmediğinde Hayat, okula dahi gidememektedir. Okula gidememek dahi onun elinde değildir. Hayat için çocukluktan çıkış da, eve dönemeyen babasını beklemekten vazgeçip bir kaçış şeklinde olur. Onun için çocukluktan çıkmak, oyuncağını denize atmakla, dedesini ölüme terk etme kötücüllüğüyle, tamirci çırağıyla boğaza açılıp etkisiz bir isyanla büyük gemilere savaş açmakla mümkün olur. Bu küçük isyanda kendisine bir "hayat kadını" tarafından hediye edilen ruju da çocukluk taraftarı olma direnciyle yüzüne boca eder. Böyle yaparak, yüzünü sarı laciverte boyayan tamirci çırağının "çocukluğu"na özeniyor ve kadınlık-erkeklik arasındaki farkları cinsiyetsiz bir düzlemde onarıyor gibidir.

Hayat'ın hikayesinde sadece "hayat" kelimesi değil, bütün olumlu çağrışımlar bir kriz yağmuruna tabi tutulmaktadır. Hayat için, modernleşme pratiklerinin onun önüne koyduğu pek çok "disipliner" kurum hiçbir anlam ifade edememektedir. Örneğin eğitim onun için iyi bir gelecek anlamına gelmemekte, aksine doğal bir dışlanmanın adresi olmaktadır. Orada eğitilen, Hayat’a karşı dışlayıcı bir tutum takınması öğretilen diğer çocuklardır. Hayat için aile kurumu da saadeti getiren bir odak olmaktan uzaktır. Aksine, aile ona ya bir yüktür ya da onun yerine kardeşiyle meşgul olan kayıtsızııktır. Hayat'ın tamirci çocuk tarafından takip edildiği sahnenin hemen arkasında, üvey

21 Yücel'e göre Hayat, sadece çocuklukla ergenlik arasında değil aynı zamanda yaşam ile ölüm arasındadır. Henüz yaşamaya karar vermemiş gibidir (Yücel, 2012: 88). 
babasının onun erkek kardeşini "Benim oğlum büyüyecek de kız peşinden koşacak" diye sevip Hayat'ı "düzgün otur" diye terslemesi erkek çocukluğun yüceltilmesine dair açık bir örnektir. Ek olarak Hayat'a lunapark bile bir eğlence vadetmemekte, aksine bir tacizin adresi olabilmektedir. İstanbul boğazının en güzel manzaraları arasında salınan Hayat'a İstanbul da aynı şekilde kötülük getirmektedir. Kadınlığa geçişte cinsellik de Hayat'a zevki değil tacizi çağrıștırmaktadır. Bu nedenledir ki öpüşen çiftlerin mutlu görünmelerine bile şaşırır Hayat. Hatta onun için güzellik de ancak büyük gemilere satılırken "bir fahişenin işini elinden alma"yı garantilemektedir.

Reha Erdem'in Hayat Var'dan 20 yıl önce çektiği ilk filmi olan A Ay (1989) da benzer şekilde küçük kız Yekta'nın büyüme sancısına odaklanmaktaydı. Eski bir konakta, Paşa torunu asil bir ailenin üyesi olan ancak buna rağmen, dedesinin gelinine tecavüzü sonucu dünyaya gelen Yekta, klasik müzikle, edebi derinlikle ve İstanbul siluetleriyle estetize edilen bir sahneleme içerisinde yer alır. ${ }^{22}$ Film boyunca yitip giden annesini aramakta, hiç kimselerin görmediği gerçekleri gördüğünü düșünmektedir. Filmin sonunda kıyamet temalı bir şiirin okunduğu bir sahnede ortadan kaybolur. Hayat Var ise, $A$ Ay'dan öncelikle müzik seçimleriyle ayrılır. $A$ Ay'daki klasik müzik, Hayat Var'da kendisini arabesk müziğe bırakır. Kendi gerçekliği, programı ve "farkındalık"ı olan Yekta'dan 20 yıl sonra Hayat, annesi yaşasa dahi annesizliği kabullenmiş ve dedesinin etkisi sayesinde eski İstanbulluların ortadan kaybolmasıyla "kıyamet"in gerçekleştiğini düşünmektedir. Ancak Hayat'ın kendi dünyasının nasıl bir sinematografi ile sahnelendiğini düşünmek için öncelikle Hayat Var'ın non-diegetic (hikaye dışı) ses kurgusunu çözümlemek icap eder. Çünkü 20 yıl önce Yekta'nın dış dünyayla iletişimi, hayal dünyası ve istekleri şeffaf bir düzlemde kolaylıkla anlaşılabilir bir rota izlerken, Hayat'ın cam kırılma sesleri, uçak sesleri, polis sireni vb. non-diegetic sesler altındaki, Erdem'in (2012) deyişiyle "mırıldanmaları" sanki başka bir düzlemi işaret ediyor gibidir.

Erdem'e (2012:91) göre "(Hayat'ın) başından beri karşısında (yanında, çevresinde) onun içsel yaşantılarını ve özellikle de sıkıntı ve endişelerini dinleyecek, kendi sıkıntısı ve endişesi yapacak ve bunları anlamlı sözler ve düşüncelere dönüştürerek ona geri gönderecek bir anne-çevre olmamıştır." Bu nedenle de simgeleri dönüştürüp filtreleyemeyen uyumlu bir iç dünya olmaması, dış dünyayı toptan bir şekilde dışlamaya neden olunca Hayat'ın içinde bulunduğu ruhsal inziva, non-diegetic ses bandı ile bize aktarılır.

Daniel Frampton (2012: 24) Filmozofi adlı kitabında sosyal bilimcilerin film incelemelerinde sadece öyküleri ve karakterleri dikkate aldığını belirterek, filmin sadece öyküleme olmadığını şu şekilde açıklar:

"Film ve felsefe alanındaki pek çok çalışma, sinemayı göz ardı edip öykülere ve karakter motivasyonlarına odaklanıyor.(...) Öncelikli ilgileri filmin öyküsüdür (diyalog, olay örgüsü ve karakterlerin motivasyonları) (...) Neticede bu yaptıkları, bir grup yeni film incelemecisini hareketli ses-imajı göz ardı edip karakterlere ve öyküye yoğunlaşmaya cesaretlendirir."

22 Bu noktada $A$ Ay dışında Reha Erdem'in pek çok filminde "büyüme" temasının işlendiğine değinmek gerekir: Korkuyorum Anne (2004), Beş Vakit (2006) ve Jin (2012). Bu filmler "büyüyemeyen, büyümenin sancılı yollarından geçmek istemeyen, büyüklerin realist dünyasını görüp bu dünyaya katılmak istemeyen çocukları ve çocuk kalanları anlatır" (Yürümez, 2010:58). 
Frampton'un belirttiği gibi Hayat Var'da öykü dışı etmenler (ses, müzik, kamera açısı vb.) kız çocuğunun kadınlığa geçişini vurgulayan önemli unsurlardır: Vapur düdükleri, kırılan cam sesleri, şarkılar, silah sesleri, ambulans sireni... Hayat'ın film boyunca süren mırıldanmaları bu türden non-diegetic seslere eşlik eder. Bütün bu yıkıcı sesler mırıldanmayla "yumuşatıldığına", "sivri köşelerinin düzleştirildiğine" göre (Erdem, 2012: 91) bu sesleri Hayat'ın "dış" dünyasına değil "iç" dünyasına ait seslermiş gibi düşünmek mümkündür. Anzieu, "ses kundağı" tanımıyla ilk ruhsal alanın "ses alanı" olduğunu belirtir (Anzieu'dan Akt. Erdem, 2012: 93). Ana rahminden itibaren bebek, hem içeriden hem de dışarıdan gelen seslerle oluşan sessel bir alan tarafından sarmalanır. Bu sarmalanma bebekte kendi ile çevre arasında bir ayrım olmadığı sanısını yaratır (Akt. Erdem, 2012: 93).

Filmde tekrarlanan "non-diegetic" sesler, esasen dış dünyanın sesleridir fakat hemen hepsi maruz kalınan kurumların, insanların şiddet ve tacizini simgeleyen ve biz istemeden kulağımıza giren gürültülerin yarattığı bir "sembolik şiddet"in ipucudur. Mütecaviz seslere karşılık Hayat'ın "kendini pışpışlayan, sakinleştiren yumuşatan mırıltısı" (Erdem, 2012: 91) ise "yaşam" ile "şiddet" arasındaki dengeyi gösterir. Dedesinin boğucu öksürük seslerine uyumlu şekilde, Hayat'ın astım krizi kaynaklı nefes daralmaları, bu dengenin Hayat aleyhine bozulduğu gerileme anları gibidir. Nitekim Hayat, o boğucu öksürükleri eve hapsedip kaçarak nefes alacak ve bu sayede dengeyi kendi lehine çevirecektir.

Filmdeki seslerin kullanımını Bourdieu'nün "eril evren" analizi çerçevesinde de yorumlamak mümkündür. Bourdieu'ye göre (2015: 22) toplumsal evren, eril tahakkümü tatbik eden sembolik bir makine gibi çalışır ve bu işbölümüne dayalı eylem şemalarıyla yakından ilgilidir. Sivas'ta Aslan'la aynı hizaya sahip bir kamera kullanımı görürüz. ${ }^{23}$ Bu seçimle uyumlu biçimde Aslan'ın davranışlarını ve tepkilerini onun sesinden ve performansından duyarız. O bu sayede aktif bir öznedir. Hayat Var'da ise, kamera Hayat'ın peşine takılmış onu gözetliyor gibidir. Hayat'ın bazı tepkileri, ekran dışı sesler aracılığıyla anlatılır. Onu takip edip peşine takılan bir "erkek" de söz konusudur. Hayat, aktif bir özneden ziyade, takip edilen, "duyulan", "gözlenen" bir imge olarak vardır. Berger, "erkek eyler, kadın görünür" (men act, woman appear) sözüyle kadın bedeninin erkek gözler için resmedildiğini savunur (Berger’den akt. Sancar, 2013: 250). Filmdeki anlatı-ses tercihi ise, kadınlığı "seyirlik" haline getirmek için değil, evrenin cinsiyetçi yüzünü ortaya koymak içindir diyebiliriz. Erkekliğin inşasını deşifre eden bir film, onun öznelliğini performansı ve söz sahipliğiyle ortaya koyarken, kadınlığın inşasını deşifre eden bir film, onun hayal kırıklıklarını, kendi sesiyle değil başka seslerle gösterir.

Yaşanan deneyimin kronolojisini ikinci plana atan ve kimi zaman olay anını da köpürtmeyen Erdem'in kurgu tarzı, Hayat'ın deneyiminin "olay anı" dışında "an sonrası ve öncesi” ile daha belirginleşeceğini gösterir. Nitekim Hayat Var'da en çok duyulan seslerden biri olan ve filmde adeta bir hayalet gibi dolanan cam şangırtısı sesinin hikayedeki anlamını komşu kadının tecavüzcü bakkalın camlarını kırdığında anlarız:

"O ayna tecavüzü görmüş olan aynadır. Tecavüz belki sessizce geçilmiş

23 Yönetmen Kaan Müjdeci bir röportajında kameranın bilinçli olarak karakterlerin tümünün göz seviyesinde tutulduğunu söylemiştir. Kaan Müjdeci ile röportaj, http://eksisinema.com/roportaj-kaan-mujdeci-sivas/ (Erişim tarihi, 01.11.2017) 
görünür ama filmde cam şangırtısını her duyduğumuzda, daha biz bilmezden önce bile aslında oradadır, kulağımıza batar ve bizi tecavüzün tanığı yapar (Erdem, 2012: 95 )".

Sadece hikayesiyle değil, ses ve kurgu tercihiyle de Hayat Var, çocukluğu alegorik bir şekilde yani yetişkinlere ışık tutan bir reçete olacak şekilde kurgulamaz. Çocukluktan söküp çıkarılabilecek erdemlerin varlığına inanmaz. Çocuğun inşa edilmesinin, onun nefesini, sesini, giyimini ve cinsel kimliğini tamamlayan sonuçlarına değinir. Çocuğun günlük hayatta salınan deneyimini ise "buz dağının görünen kısmı" kısıtlılığında olduğunu ortaya çıkar. Hayat adına kararların bu toplumsallıkta verildiğini ancak Hayat'ın bir yönüyle de kendi doğasına sıkı sıkıya bağlı ${ }^{24}$ bir fonksiyon olduğunu söylüyor gibidir. Bu nedenledir ki, toplumsal kurguların egemenliği, Hayat'ın kendi başına buyruk aldığı "boyundan büyük" kararları (evlenme teklif etmek, dedesini ölüme terk etmek gibi) yok saymak anlamına gelmez. Yanı sıra Hayat Var, özellikle Hayat'ınki gibi deneyimlerin, çocukluk krizlerini sağ salim aşmak istediğinde hemen tüm yolların yürünemez, denizlerin aşılamaz ve sesin çıkamaz oluşunu göstermesi bakımından ilginçtir. Çünkü bu sayede "iyileştirme"yle özdeşleşen modern kurumların hemen hepsinin bu yarayı kaşıdığını, zenginlikle özdeşleşen İstanbul Boğazı'nın bile dibinde taşra yarattığını ve büyümeyle ya da boyamayla kapanacak zannedilen boşluğun hiç kapanmadığını hatırlatır.

\section{Sessizlikle Değil Erkeklik Çağrısıyla İmtihan Olan Aslan}

Hayat’tan 2-3 yaş küçük erkek çocuk olan Sivas (2015, Yön: Kaan Müjdeci) filminin Aslan'ı ise, Yozgat'ın bir köyünde yaşayan bir erkek çocuktur. Reha Erdem'in gerçeküstü film anlayışı, Hayat'ı adeta dikizleyen sabit kamera kullanımı ve ekran dışı ses kurgusunun aksine bu filmde, Kaan Müjdeci tarafından Aslan'la aynı hizada kamera kullanımı, gerçek sesler ve gerçekçi bir anlatım dili benimsenmiştir.

Aslan, annesi, babası ve özellikle köydeki erkeklerin alay ettiği abisiyle yaşar. Aslan'ın gözü köyün varlıklı üyesi olan muhtarın oğlunun beslediği dövüş köpeğindedir. Hayat'ın tersine Aslan'ın önünde abisi gibi "kötü” bir örnek ve muhtarın oğlu gibi "makbul" bir örnek vardır. Muhtarın oğlu, Connell'in "hegemonik erkeklik" modelindeki gibi köyün erkeklerine çağrıda bulunan bir kişiyken, Aslan'ın abisi bu erkek tipinin ezdiği "eksik" erkeklik tipini sembolize eder.

Öncelikle köyün erkeklerinin ilişki ağı, homo-sosyal bir erkek topluluğu olarak tanımlanabilir. Bu erkeklerin Bourdieu'nün yukarıda andığımız "homo-sosyal rekabet oyunları"na düşkün olduğu görülmektedir. Erkekliğin performe edildiği köpek dövüşü ve silah çevirme oyunları buna örnektir. Homo-sosyal topluluklar, erkek egemenliğini yeniden üretip vurgulayarak, erkeklerin karşılıklı olarak normalliğini ve varlıklarını meşrulaştırır (Onur ve Koyuncu, 2014:39). Homo-sosyal toplulukların bir başka özelliği ise erkeklikle ilgili aşağılayıcı espirilerin yapılmasıdır. Bu durum erkekler üzerinde kaygı ve baskı yaratır (Cengiz, Tol ve Küçükural, 2014: 59). Köydeki "hegemonik

24 Yönetmen, diğer filmlerindeki Beş Vakit (2006) ve Jin (2013) kız/erkek çocukların çocukluklarında da sık sık doğada otlar, çalılar arasında uyuyan çocuklara yer verir. Çocukluğu, her türlü toplumsal kurguya, işlenmeye rağmen doğadan fışkırmış bir neşne olarak düşünüp insanı bu yüzüyle de değerlendirmek gerektiğini vurguluyor gibidir. 
erkeklik"e tabi söylemlerin, Aslan'ın abisinin erkekliğiyle ilgili yaptığı şakalar, Aslan'ın gözü önünde gerçekleşir ve Aslan için "erkekliğe geçiş" bu çağrı etrafında şekillenir.

Gün geçtikçe, edindiği dövüş köpeğinin sağladığı güçle, okuldan ayağı kesilecek Aslan, okulda Pamuk Prenses ve Yedi Cüceler temsilinde öğretmenin kendisine "cüce" rolü vermesine, muhtarın oğlunun ise doğal "prens" olmasına tepkilidir. Hayat'ın yalnızlığının tersine, Aslan, "prenses” rolünü oynayan Ayşe’ye aşıktır. Okulun kitabi gerçekliği, Hayat gibi Aslan'a da cazip gelmez. Prens rolüne talip olmak ve muhtarın oğlundan ne eksiği olduğunu öğrenmek için öğretmeninin evine gider. Öğretmeni ise konuyu değiştirmek için Aslan'a zor matematik soruları sorar. Öğretmen'in Aslan'ın talebiyle ilgili kayıtsızlığı aynı zamanda bu konuda onu da aşan bir "eril evren" olduğunu düşündürür ve bir "muktedirsizliği" işaret eder. Muhtar'ın "hegemonik erkekliği" ve "kültürel ve sosyal sermaye" $\mathrm{j}^{25}$ ise bu konuda baskındır ve cinsiyeti toplumsal alanda işleten hegemonyanın öğretmeni (okulu) de aşan işlevselliğini ortaya koyacak niteliktedir.

Böylece, henüz daha çocukken kendisini "kadınlığın” içinde bulan Hayat gibi, çocuk Aslan da krizinin sınanan erkekliğinin noksanlığı üzerinden geliştiğini fark eder. Bu açığı kapatmak için yakaladığı fırsat, öldü zannedilerek terk edilen dövüş köpeği Sivas'tır. Sivas'ı yaşatıp başarılı bir dövüş köpeğine dönüştüren Aslan, bu sayede erkekliğini onararak söz hakkına sahip olur.

Böylelikle ilk bakışta çocuksu gözüken bir oyunun, hegemonik erkeklik merkezli“erkeklik habitusunun" çağrısıyla bir yetişkin oyununa dönüştüğü görülür. Walter Benjamin, 19. Yüzyıla kadar oyuncak üretiminin özgün bir meslek haline gelmediğini, oyuncakların zanaat üretiminin bir parçası olduğunu, örneğin tahta atların tornacılarda, kurşun askerlerin kazancılarda, meyankökü figürlerin şekerlemecilerde bulunduğunu ifade eder (Benjamin, 2001: 64-65). Şüphesiz endüstrileşmeyle birlikte yeni sektörlerin ortaya çıkması, yetişkin eliyle çocuğa sunulan rollere uygun kontrollü oyuncakları ortaya çıkarmıştır. Ancak, çocukluktan çıkış bu oyuncakların da işlevsizleştiği, çocukların yetişkin oyunlarına göz diktiği bir sürece işaret eder ve artık, çocukluğa sunulan bir oyuncaktan değil, çocuğun yetişkinlik dünyasındaki farklı mekanlardan topladığı gerçekliklerle meşgul olduğu daimi bir oyun alanından bahsedilmektedir.

Psikanalist Eric Berne (1998:73), toplumsal etkileşimleri "yetişkin”, "anne-baba” ve "çocuk" karakterleri üzerinden şemalarla değerlendirir ve bu karakterlerin birbirlerinin rollerini çaldığını ve hatta birbirinin yerine geçtiği durumları da örnekler. Yetişkin oyunu olarak köpek dövüşünün, hem yetişkinlerin hem çocukların hem de hayvanların "gönüllü"26 rollerinin bir kesişim düzleminde oluşması oldukça semboliktir. Bu sayede tüm roller arasında sahici bir etkileşim kurulur. Huizinga da (1995: 18) oyunun kültürden eski olduğunu söylerken aynı düzleme vurgu yapmaktadır. Kısacası Sivas'taki oyunlar

25 Bourdieu'ye göre sermaye, sadece maddiyat odaklı değildir. Bireylerin içerisinde bulunduğu toplumsal konumlarının ve ilişkiler ağının onlara sağladığı sosyal avantajlar söz konusudur. Bireylerin kültürel sermayeleri, nesilden nesile aktarılır. Çocukların, okuldan alabileceklerinin potansiyeli de ailenin kültürel sermayesinin sağladığı avantajlar sayesinde daha fazla ve baskın olabilir (Jourdain- Naulin, 2016). Bu kavramlar ışığında muhtarın "sosyal sermayesinin" diğer köy halkına göre baskın olduğu ve oğlunun okulda sağladığı avantajın ise "kültürel sermaye" kavramı ışığında değerlendirilebileceği söylenebilir.

26 "Oyun aynı anda hem hayvanlar alemini hem de insanlar alemini kapsar. Bunun sonucu olarak rasyonel iliski üzerinde temellendirilemez." diyen Huizinga'ya göre oyun, gönüllü bir eylemdir. Zorunlu değildir (Huizinga, 1995: 24). 
merkezi bir el tarafından değil, anonim bir geçmiş itkisi tarafından, kültürel bellek ve kahramanları değişebilecek "hegemonik erkek" tarafından yönetilir.

Berne'e göre (1998:73) oyunlar, belirlenmiş uyarı ve tepki biçimlerini aldıktan sonra kökenleri zamanın sisi içinde kaybolmakta ve kökenleri toplumsal karmaşıklığın içinde saklı kalmaktadır. Sivas'ta "esas derdi çoktan gizlenip yok olmuş" bu türden anonim oyunlardan biri de erkeklerin kendi arasında oynadığı hızlı silah çekme oyunudur. Bu sayede erkekliğin yeniden üretimi de yetişkinliğe geçişin görünmez giysisi haline gelir. Oyunun kültürel bir işlev kazanması, "görevlerin, ödevlerin ve zorunlulukların" devreye girdiğini gösterir (Huizinga, 1995: 24-25).

Filmin başında yaşıtı arkadaşlarıyla torpil patlatan, oyuncak füze uçuran Aslan, filmin sonunda iktidar aygıtına ve yetişkinler dünyasına ortaktır. Aslan'ın yeni oyuncağı yetişkinlerin "homo-sosyal oyunundan" arta kalan ve onun kendi elleriyle hayat verdiği bir dövüş köpeğidir. Ona kalan bu oyuncakla, yetişkinleri kendi silahıyla vurur. Zira oyunlar, çocuğun kişiliğinin yetişkin tarafıyla düzenlenir (Berne, 1998:73). Böylece oyuncak mülkiyeti de, yetişkinin lütfedip sunmasıyla değil bir yetişkin gibi savaşarak elde edilen bir güç ile elde edilir. Yetişkinlik, erkekliğin kapısından girilirken, hangi güce sahip olup olmadığının sorgulandığı bir geçiş kapısıdır, güç gösterisidir. ${ }^{27}$ Çocukluktan çıkış, Hayat'ın çocukluğu gibi her şeyin geride bırakılarak kaçıldığı bir isyan değil beyaz atlı olmasa da beyaz köpekli ama illa ki gözle görülür bir güce sahip olunarak girilen bir dünyadır. Hayat, çerçevenin dışına çıkarak özgür olabilirken Aslan, çerçevenin içinde güçlenerek özgürleşir. O oyuncağı kaybetmek, köpeğin ölme ihtimali, Aslan için sadece sıfıra dönüş değil aynı zamanda cüce rolü biçilmiş bir çocukluğa dönüş olacaktır. Yoksa abisi gibi "hep çocuk", "köyün meczubu" ve "eksik erkek" olarak kalması mümkündür. Hayat'ın karşılaştığı erkekliğin tacizkar müdahalesiyken, Aslan'ı sınayan erk, erkeklik davetiyesini gösterir. Okul çıkışında bekleyip arkadaşlarına savaşçı dövüş köpeğini gösteren Aslan'a karşın Hayat, sınıf arkadaşlarına bakkalın tacizleri karşılığında aldığı çikolataları dağıtarak kendini kabullendirmeye çalışır. Yanı sıra Hayat'ın vasıtasızlığının tersine Aslan, edindiği bu yeni yetişkin oyuncağı sayesinde kendi isteğiyle okula gitmeme imtiyazına sahip olur.

Aslan'la yüceleşen veya Hayat'la sessizleşen her iki yetişkinliğe geçişin cinsellikle ilişkisi de bu ikiliğin hem sebebi hem de sonucudur. Sivasta görünen erkek cinselliği, Hayat'ın yaşadığı sessiz travmanın aksine erkek çocuğun yanında övülerek anlatılan bir performanstır. Yıkanırken annesinin göğüslerine gözü giden Aslan²8, köyün diğer erkekleriyle yakın zamanda gideceği muhtemel bir genelev ziyaretinde abisi gibi bir "aslan parçası"na dönüşecektir. Bu noktada film, zengin olmasına rağmen, sırf bu yüzden doğal olarak tiyatro temsilinde Prens rolünü kapan "diğer çocuk" muhtarın oğlunu derinleştirmemeyi tercih etmiştir. Halbuki o karakter de, elinde sahip olduğu şeyi sürekli kaybetme korkusuyla yaşayan, sürekli bir ispata çağrılan erkek çocukluğun diğer yüzüdür.

27 Çocukluğun bu karnavalesk güç gösterisine yine yakın zamanlı bir örnek de Kış Uykusu'ndaki (2013, Yön: Nuri Bilge Ceylan) çocuk illyas'ı́r. Ailesini kira için sıkıştıran zengin ailenin arabasının camını kırar. Özür dilemek için el öpmesi istendiğinde de itaatsizliğini sürdürür. Ailesindeki yetişkinler hemen aynı şeyi düşünmelerine rağmen, bu türeylemlerde bulun(a)mazlar. Illyas ise, aile büyüklerinin değil çocukluğun izin verdiği bu alanda bir yetişkine olan tepkisini açığa çıkarır. Ancak, erkeklik, bu gösterinin alkışlandığı bir son durakken, sınıfsal hiyerarşiyi yok sayan bir itaatsizlik bu yolculukta kolay kolay inilemeyen bir duraktır.

28 Erken sosyalizasyon sürecinde, erkek çocukların düşünsel gelişimlerini belirleyen anneleri olsa da, ileri aşamada söz sahibi olan dışarıdaki erkeklik algısıdır (Onur-Koyuncu, 2004, 42). Filmde vurgulanan da erkekliğin aile dışı kurulma biçimidir. 
Bugünün çocuğu Aslan'ın, bir kuşağın çocukluğunda meşhur olan resim izleme aletiyle (View-Master) Lessie'ye ${ }^{29}$ bakması ise, nostaljik çocukluğun geride kaldığını simgeliyor gibidir. Bu sahneleme, zamanın "acıların çocuğu" oyuncu Emrah'ın Hamburger reklamında o "yetim acı"yı alaya alması gibi veya Komser Şekspir (2001, Yön: Sinan Çetin) filminde eski çocuk kahraman filmlerinin oyuncusu olarak bilinen ve şimdilerde ilgisizlikten yakınan "Hayaticik" karakteri (Tatü) üzerinden, söz konusu çağın geride bırakıldığının söylenmesi gibidir. ${ }^{30}$ Coğrafya bir kaderdir ama elde ne varsa çocuğu öyle var edecek yetişkinlik kapıdadır. Akılı köpek Lessie ile arkadaşlıkla erdem peşinde koşan çocukluğun yerini dövüş köpeği sahipliği ile iktidara ortak olabilen yeni çocukluk almıştır.

Adalet anlayışı da Aslan'a yıllarca hatırlanacak bir baba öğüdü, dini/ahlaki bir sınır olarak miras kalmamıştır. Aslan, hoşlandığı kıza kendini göstereceği tek dayanağı da tehlikeye atacak şekilde "Sivas'ı dövüştürmeyeceğim" diyerek kendi adalet anlayışını dayatır. Artık, bu buyruğa itaat etmesi beklenen çocuklar değil yetişkinlerdir. Karşılarında artık, bir çocuk değil, bir "hegemonya" vardır. Ancak bu direnişe karşın, "hegemonik erkekliğin" merkezi olan muhtar, filmin final sahnesinde, Aslan'ı ikna etmek için "o bir it, dövüşmek onun doğasıdır. İt olarak doğmuş. O bir aslan değil!" merkezli bir konuşma yapar. Bu son söz, erkekliğin toplumsal işlevinin, onun biyolojik cinsiyetini doğallaştırarak işlediğini hatırlatan simgesel bir söylemdir. Aslan'ın bu "çocuksu itirazı"na karşı hegemonik erkekliğin gösterdiği yol, "itini dövüştürmesi" ve bu sayede "erkek" olmasıdır. Bu nedenledir ki, erkekliğin gösterimi ve sürekli gereken ispatı da "çocuklukta çakılı kalma" korkusuyla hoyratlaşır. Erkekliği hakkıyla yaşayamama tehlikesi, "büyümemişlik" damgasıyla dövülür.

Aslan da bu nedenle kimliğini yetişkinlikten ödünç ya da miras almaz. Bir model bularak öykündüğü öğretmen ya da baba figürü yoktur. O bizzat kendi gücüyle olarak var olur ve tüm iplerini eline alır. Aile ve okul üstü bir konumda buyurgan hale gelir. Sınavı savaşarak geçmiştir. Böyle olunca da çocukluk, "hayali" köyde naifçe hatırlanan bir siyah beyaz film karesi değil, yetişkinliğin mayasını oluşturan tüm renklerin kesiştiği bir mekanda yaşanan gerçeklik haline gelmiştir. Bu gerçeklik, çocuğu "noksan yetişkinlik" olarak değil "başka" ve "tam" bir çocuk olarak temsil eden bir örnektir.

Çocukluk, merkezi basınçla değil, bizzat o mekanı yaratan ve haliyle mekanda zaten var olan kışkırtmalarla büyür. Aslan'ın köyündeki erkeklerin hızlı silah çekme yarışması bu kışkırtmaya klasik bir örnektir. Ancak, Sivas'ın estetik başarısı, yetişkinin pedagojisinin işlevsizliğini göstererek, çocuğun okulu bırakmaya kadar giden savaşçı potansiyelini işleyebilmiş olmasıdır. Böylelikle, doğuştan erdemli çocuğun iflası, küfreden, ailesine karşı çıkabilen ve okul çıkışında dövüş köpeğiyle bekleyen asi çocuk üzerinden ilan edilir.

29 Amerikan sinemasındaki çocukluk imgelerinden birisi de onun zeki köpek Lessie ile başarılara ulaşmasıdır. Onun dışında 1930'larda Amerika'da yaygınlaşan ilk çocuk kahraman film serisi olan Shirley Temple serisinin Yeşilçam filmlerindeki çocuk kahramanlı filmlere ilham kaynağı olduğuna dair görüşler vardır. Bu sahne metaforik olarak değerlendirebileceğimiz söz konusu filmlerdeki çocuk kurgusunun hicvedilmesi olarak okunabilir.

30 Uzun süren "acıların çocuğu" filmlerindeki başa çıkılması gereken biçare öksüzlüğü kendisi dahi gündeme getirmek istemeyen oyuncu/sanatçı Emrah, nihayet 2014'te bir hamburger firmasının reklamlarında "acıların çocuğu" başııkı reklam sloganı altında oynayarak o dönemin çocukluğunun geride kaldığını bir kez daha kendi ağzından ilan ediyordu. Suner ise (2006:21) Hayaticik karakterinin filmin sonundaki tiyatro temsilinde çocuk rolüne girmesinin, melodramla komediyi kesiştirdiğini ve izleyicilerin Hayaticik'in çocuk oyuncu olduğunu anımsaması ve onu takdir etmesiyle "çocuksu toplum" düşüncesinin yeniden ana akım sinemada ancak farklı bir veçheyle alımlandığını tespit eder. 
Son olarak, Aslan'ın okula gitmemesi dahi bir cezanın değil bir oyunun malzemesi haline gelir. Cezalandıran, buyuran, mülkiyetini koruyan ve aşkının peşinden giden Aslan'ın çocukluğu yetişkinliğin "hayal ettiği” belli belirsiz bir etkisiz eleman değil nostaljik çocuğu geride bırakan ve yetişkinlikte gözü olan bir çocukluğun temsili olarak okunmalıdır. Dövüş köpeğinin toplumsal işlevi Aslan'ın çocuk kalma korkusuyla sarıldığı bir limandır. Sivas'a zaten dövüştüğü için ilgi duyan Aslan'ın 'Üşüdün mü oğlum?'dan 'Dövüş oğlum!'a geçtiğini düşünmek de yanıltıcı olacaktır. Buradaki geçiş, kötülüğe doğru bir gidiş değil yetişkinliğe doğru bir gidiştir.

\section{Sonuc}

Bourdieu, (2015:98-102) erkeklerin toplumsal oyunlara yatkın olduğunu söylerken, kadınların da bu oyunların pasif izleyicisi olarak kurgulandığını ve oyun oynayan erkeklere bağımlı olduklarını belirtir. Sivas filmi, homo-sosyal erkek oyunlarının "hegemonik" erkeklik merkezli bir köyde, performatif erkekliği ve gücü nasıl işlevselleştirdiğini ve büyüttüğünü ortaya koyarken, Hayat Var filmi, çözümü, sürekli maça giderken gözlediği futbol taraftarı olan yaşıtı erkekle kaçmakta bulan ve içeriden değil dışarıdan gözlediğimiz bir Hayat karakteriyle toplumsal dünyamızda kadınlığa geçişin nasıl içselleştirildiğini ortaya koyar.

Çocukluğun Yeni Türkiye Sineması'nda yetişkinliğe geçiş dönemi olarak görünür olması, toplumsal cinsiyetin "erkek" ve "kadın" üzerinde işlettiği rol dağılımına bakmayı zorunlu kılar. Toplumsal hayatta bu geçiş, tam anlamıyla, "hakkıyla" yerine getirilmeden çocuklar erkekliğe ya da kadınlığa yani yetişkinliğe adım atmış sayılmazlar. $O$ halde çocukluğu "iyi" anlattığı düşünülen filmler, tamamlanmanın estetiğini ortaya koyabilen çalışmalardır. Yani onu kullanışı modernliğiyle ele alan "erdemler sineması"nın değil de onun yetişkinliğe geçişte neleri sırtladığını ortaya seren "deneyimler sineması"nın toplumsal işlevi üzerinde durmamız bu yüzden önemlidir. Bu da Yeni Türkiye Sineması'nda "metaforik" anlatı tarzından "metonimik" anlatı tarzına geçişin çocuk karakterli filmlerde de söz konusu olduğunu gösterir. Hatta bu deneyimlerin, inşacı söylemlerin daha iyi anlaşılmasına hatta bu söylemlerin deşifre edilmesine katkı sağladığını da söylemek gerekmektedir.

Literatürde çocukluğun politik ve sosyal olarak inşa edildiğine ilişkin çok sayıda çalışma vardır. Ancak bu inşanın en önemli kurumlarından birisi olarak değerlendirilen okul ve ailenin, Yeni Türkiye Sineması'ndaki çocukluk kurgularında tuhaf biçimde etkisizleştiğini gözlemek mümkündür. Okul, çocukluğun inşası için önemli bir kurum olmakla beraber, onun toplumsallaşmasındaki nihai karar verici mekan değildir. Bunun yerine çocukluk sosyalizasyon sürecindeki diğer etmenlerin etki alanı içerisinde de değerlendirilmektedir. Hatta bu disipliner mekanizmanın, tıkır tıkır işleyen bir aygıta benzemediği, aksine yeni krizler ve sorunlar doğurduğu bu sinema dili sayesinde çözümlenebilir. Bu çözümleme çabası, çalışmamızda "erkeklik habitusu", "hegemonik erkeklik" ve "uzlaşmacı kadınlığa geçiş" gibi anahtar sosyolojik kavramlar üzerinden gerçekleştirilmiştir. Bu nedenle sinemadaki çocukluk deneyimlerinin analizinin, çocuk kategorisinin biyolojik varlığının toplumsal boyutunun daha iyi anlaşılabilmesi adına araştırmacılara sunacağı önemli ufuklar olduğunu söylemek mümkündür. Çocukluğun sosyo-politik inşasını ve büyümesini deneyimler üzerinden analiz etmek, kadınlığa ve erkekliğe geçişin formülasyonları hakkında bize önemli ipuçları sunmaya devam etmektedir. 
Her iki filmde de yetişkinliğe geçiş, güç ve oyun bağlamında analiz edilerek, toplumsal alanda işleyen iktidar düzenekleri karşısındaki çocukluğun önemi ortaya konulmaktadır. Çocukluğu inmal ederek, kadınlık ve erkeklik kimliklerini analiz etmek mümkün gözükmemektedir. Bu nedenle, "erkeklik çalışmaları" ve "kadınlık çalışmaları"nı zenginleştirecek olan çabalardan birinin "çocuk gözüyle bakış"ı da incelemekten geçtiği söylenebilir. Sonuç olarak sinemadaki çocukluk kurgularının deşifresi, çocukluğun hem politik ve sosyal bir alegori olarak kullanılabilirliğini ortaya koymakta hem de "büyüme"nin sancılı doğasını anlamayı kolaylaştırmaktadır.

\section{Kaynakça}

Abisel, Nilgün (1994). Türk Sineması Üzerine Yazılar, İstanbul: İmge.

Ariés, Philippe (1962). Centuries of childhood: a socialhistory of family life. Translated by Robert Baldick. New York: Vintage Books.

Atay, Tayfun (2004). Erkeklik En Çok Erkekliği Ezer, Toplum ve Bilim, Güz, Sayı:101:11-31.

Arslan, Tümay (2004). Yeşilçam'ın Erkekleri Ne İstiyor, Toplum ve Bilim, Güz, Sayı:101:162192.

Berktay, Fatmagül (2016). Tek Tanrılı Dinler Karşısında Kadın, İstanbul: Metis.

Berne, Eric (1998). Hayat Denen Oyun, Çev: Selami Sargut, Kariyer Yayınları.

Benjamin, Walter (2001). Çocuklar, Gençlik ve Eğitim Üstüne, Ankara: Dost.

Bourdieu, Pierre (2015). Eril Tahakküm, Çev:Canan Suner, İstanbul: Bağlam.

Cengiz, K. Tol; Ulaş, Uğraş; Önder Küçükural, (2004). Hegemonik Erkekliğin Peşinden, Toplum Bilim, Güz, Sayı:101:50-71.

Connell, R.W. (1998). Toplumsal Cinsiyet ve İktidar, Çev: Cem Soydemir, İstanbul: Ayrıntı.

Emre, Kumru Berfin (2007). Ayşecik Filmlerinde Çocukluk Temsili, Anadolu Üniversitesi Sosyal Bilimler Enstitüsü, Yayımlanmamış Yüksek Lisans Tezi, Eskişehir.

Erdem, Nilüfer (2012). Hayatın Mırıltısı, "Sinema ve Psikanaliz" içinde (der.) Özden Terbaş, İstanbul Bilgi Üniversitesi Yayınları.

Foucault, Michel (2000). Hapishanenin Doğuşu, Çev: Mehmet Ali Kılıçbay, İstanbul: İmge.

Frampton, Daniel (2013). Filmozofi, Çev: Cem Soydemir, İstanbul: Metis.

Gürbilek, Nurdan (2016). Kötü Çocuk Türk, İstanbul: Metis.

Gürses, İlknur - Becerikli, Rıfat (2016), Reha Erdem Filmlerinde Erkeklik Arketiplerin Yeniden

Üretimi, Uluslararası Sosyal Araştırmalar Dergisi, Cilt:9, Sayı:42.

Huizinga, Johan (2013). Homo Ludens Oyunun Toplumsal İşlevi Üzerine Bir Deneme, Çev: Mehmet Ali Kılıçbay, İstanbul: Ayrıntı.

Jusdanis, Gregory (2015). Gecikmiş Modernlik ve Estetik Kültür, Çev:Tuncay Birkan, İstanbul: Metis.

Kellner-Ryan Michael -Douglas (2010). Politik Kamera, Çev.: Elif Özsayar, İstanbul:Ayrıntı.

Kızıldaş, Burçin Kalkın (2016). Taşrada Kalan Erkeklikler, SineCine Sinema Araştırmaları

Dergisi, Güz, 7(2):71-94. 
Sancar, Serpil (2013). Erkeklik: İmkansız İktidar, İstanbul: Metis.

Naulin, Sidonie - Jourdain, Anne (2016). Pierre Bourdieu'nün Kuramı ve Sosyolojik Kullanımları, Çev: Öykü Elitez, İstanbul: İletişim.

Onur, Hilal- Koyuncu, Berrin (2004). Sosyalizasyon Sürecinde Erkeklik, Toplum ve Bilim, Güz, Sayı:101:31-50.

Özarslan, Aylin Dikmen (2017). Çocuk ve Çocukluk Sosyolojisi, İstanbul: Resse.

Postman, Neil (1995). Çocukluğun Yokoloşu, Çev: Kemal İnal, Ankara: İmge.

Sunal, Ali Kemal (1998). TV ve Sinemada Kemal Sunal Güldürüsü, Marmara Üniversitesi Sosyal Bilimler Enstitüsü, Yüksek Lisans Tezi, İstanbul.

Sunal, Kemal (1990). TV ve Sinemada Kemal Sunal Güldürüsü, İstanbul:Sel Yayıncılık.

Suner, Asuman (2006). Hayalet Ev: Yeni Türk Sinemasında Aidiyet, Kimlik ve Bellek, İstanbul: Metis.

Swartz, David( 2011). Kültür ve İktidar: Pierre Bourdie'nün Sosyolojisi, Çev: Elçin Gen, İstanbul: İletişim.

Yücel, Fırat (Ed.) (2009). Reha Erdem Sineması: Aşk ve İsyan, İstanbul: Çitlembik Yayınları.

Yücel, Fırat (2012). Hayat Var: Bir Kapıdan Gireceksin, "Bir Kapıdan Gireceksin: Türkiye Sineması Üzerine Denemeler" içinde, Arslan, Umut Tümay (Ed.) İstanbul: Metis.

Yüksel, Gülay (2013). Eleştirel Bir Ömer Kavur Filmografyası Denemesi, Yakın Doğu Üniversitesi Sosyal Bilimler Enstitüsü, Yayımlanmamış Yüksek Lisans Tezi, Lefkoşa.

Yürümez, Serkan (2010). Toplumsal Cinsiyet Kalıplarının Reha Erdem Sinemasında Kadın ve Erkek Karakterlere Yansımaları: Korkuyorum Anne ve Hayat Var Filmlerinin Analizi, Beykent Üniversitesi Sosyal Bilimler Enstitüsü, Yayımlanmamış Yüksek Lisans Tezi, İstanbul.

Winnicott, D.W. (2003). Oyun ve Gerçeklik, Çev: Tuncay Birkan, İstanbul: Metis.

\section{Yazıda Adı Geçen Filmler}

A Ay (1989). Yön: Reha Erdem, Metis Film.

Ayşecik Şeytan Çekici (1960). Yön: Atıf Yılmaz, As Film.

Babam Askerde (1995). Yön: Handan İpekçi, Yeni Yapımlar.

Bal (2010). Yön: Semih Kaplanoğlu, Kaplan Film.

Beş Vakit (2006). Yön: Reha Erdem, Atlantik Film.

Büyük Adam Küçük Aşk (2001). Yön: Handan İpekçi, Yeni Yapımlar.

Canım Kardeşim (1973). Yön: Ertem Eğilmez, Arzu Film.

Dar Alanda Kısa Paslaşmalar (2000). Yön: Serdar Akar, Umut Sanat.

Duvar (1984). Yön: Yılmaz Güney, Güney Film.

Düttürü Dünya (1988). Yön:Zeki Ökten, Şeref Film.

Eşkıya (1996). Yön: Yavuz Turgul, Filma Cass. 
Gelin (1973, Yön: Ö. Lütfi Akad, Erman Film.

Hayat Var (2008). Yön: Reha Erdem, Atlantik Film.

İki Dil Bir Bavul (2009). Yön: Orhan Eskiköy, Özgür Doğan, Bulut Film.

Jin (2012). Yön: Reha Erdem, Atlantik Film.

Kasaba (1987). Yön: Nuri Bilge Ceylan, NBC Film.

Kış Uykusu (2013). Yön: Nuri Bilge Ceylan, NBC Film-Zeyno Film.

Komser Şekspir (2001). Yön: Sinan Çetin, Plato Film.

Kuzu (2014). Yön: Kutluğ Ataman, Saatleri Ayarlama Enstitüsü.

Mavi Bisiklet (2015).Yön:Ümit Köreken, Drama Film.

Öğretmen (1988). Yön: Kartal Tibet, Uğur Film.

Rauf (2016). Yön:Soner Caner-Barış Kaya, Aslan Film.

Sezercik Küçük Mücahit (1974). Yön: Ertem Göreç, Er Film.

Sivas (2015). Yön: Kaan Müjdeci, Coloured Giraffes.

Uçurtmayı Vurmasınlar (1989) Yön: Tunç Başaran, Magnum Film.

Yusuf ile Kenan (1979) Yön: Ömer Kavur, Alfa Film.

Vizontele (2001). Yön: Yılmaz Erdoğan, BKM Film. 